\title{
Property Rights and the Economy of Nature: Understanding Lucas v. South Carolina Coastal Council
}

\author{
Joseph L. Sax*
}

\section{INTRODUCTION}

\section{A. The Setting of Lucas in the Supreme Court}

There was every reason to expect 1992 to be a year of dramatic change in the constitutional law of takings. The United States Supreme Court granted certiorari to four cases involving takings issues, each of which could have led to major revisions in takings jurisprudence. In PFZ Properties, Inc. v. Rodriguez, ${ }^{1}$ a Puerto Rican land developer claimed that the government had effectively denied him the right to use his property through its delay and evasiveness in acting on his permit application. The Court could have used Rodriguez to define constitutional limits on anti-development tactics, but instead it dismissed the writ following oral argument. ${ }^{2}$ General Motors Corp. v. Romein ${ }^{3}$ involved a regulatory law which upset contractual arrangements between an employer and its employees regarding workers' compensation benefits. While it appeared that the Court might revisit the retroactivity doctrine, instead it affirmed the validity of retroactive economic regulation, just as it has done several times in recent years. ${ }^{4}$ Retroactivity doctrine is important to takings cases because it potentially limits the application of new regulatory standards to existing contractual relationships such as that of employer and employee. Yee v. City of Escondido ${ }^{5}$ concerned the validity of a rent control ordinance applied to rentals of mobile home pads. ${ }^{6}$ The Court

* James H. House and Hiram H. Hurd Professor, University of California, Berkeley, School of Law (Boalt Hall).

1. 928 F.2d 28 (1st Cir.), cert. granted, 112 S. Ct. 414 (1991).

2. $112 \mathrm{~S}$. Ct. 1151 (1992). In addition, certiorari was denied in a California case involving farreaching development exactions, one of the most controversial contemporary property issues. Commercial Builders v. City of Sacramento, 941 F.2d 872 (9th Cir. 1991) (holding that a city ordinance, conditioning nonresidential building permits on payment of a fee to offset burdens caused by lowincome workers employed on a project, was not an unconstitutional taking), cert. denied, $112 \mathrm{~S}$. Ct. 1997 (1992).

3. 112 S. Ct. 1105 (1992).

4. See, e.g., Connolly v. Pension Benefit Guar. Corp., 475 U.S. 211 (1986); Usery v. Turner Elkhorn Mining Co., 428 U.S. 1 (1976).

5. 112 S. Ct. 1522 (1992).

6. The owner claimed that a departing tenant who was selling his mobile home could capture the value of the controlled rent in the price charged for the mobile home. Thus, the owner argued, 
granted certiorari on several potentially far-reaching issues, among them whether the ordinance denied the landowner substantive due process. Had Yee prevailed on that ground, it would have portended greatly increased judicial involvement in property cases, opening an opportunity for courts to overturn legislative judgments in ways that have not been seen since the era of Lochner v. New York. ${ }^{7}$ The Court, however, declined to decide the substantive due process issue and refused to revisit the basic question of whether rent control is a taking. Rather, it limited its decision to a position it had anticipated in an earlier case, ${ }^{8}$ that its Loretto physical invasion test ${ }^{9}$ would not apply where possession had been voluntarily granted by the owner, such as under a lease. In the end, out of four potentially significant takings cases, the Court wrote an extensive and doctrinally significant opinion in only one: Lucas v. South Carolina Coastal Council. ${ }^{10}$

\section{B. Lucas: The Facts and the Decision}

In 1986, David Lucas bought two lots on the Isle of Palms, a barrier island east of Charleston, South Carolina. ${ }^{11}$ Although beachfront properties had been subject to development restrictions since 1977, Lucas' lots were landward of the restricted area and originally zoned for development as residential homesites. In 1988, however, South Carolina enacted new restrictions in the Beachfront Management Act: ${ }^{12}$ Construction of improvements, except for narrow wooden walkways and decks, was prohibited seaward of a setback line that was based on historic movements of high water during the previous forty years. The following legislative findings served as a basis for the Beachfront Management Act: (1) the beach/dune system along the coast protected life and property by serving as a storm barrier, dissipating wave energy and contributing to shoreline stability; (2) many miles of beach were critically eroding; (3) the beach/dune system provided both the basis for a tourism industry important to the state and an important habitat for plants and animals; (4) development would endanger adjacent property; and (5) various protective devices such as seawalls had not proven effective against the harmful impacts of development. ${ }^{13}$ All of Lucas' land was within the newly protected zone.

Lucas filed suit, claiming that the Act's ban on construction effected a

the benefit of rent control did not go to the new tenant but was capitalized and carried away by the departing tenant, undermining the purpose of rent control.

7. 198 U.S. 45 (1905). Justice Stevens' dissent in Lucas suggests that the majority opinion signals a reversion to the Lochner era, with courts "denying the legislature much of its traditional power to revise the law governing the rights and uses of property." Lucas v. South Carolina Coastal Council, 112 S. Ct. 2886, 2921 (1992) (Stevens, J., dissenting).

8. FCC v. Florida Power Corp., 480 U.S. 245 , 252-53 (1987).

9. See Loretto v. Teleprompter Manhattan CATV Corp., 458 U.S. 419 (1982) (ruling that permanent physical occupation of property constitutes a taking).

10. 112 S. Ct. 2886 (1992).

11. Almost all of the factual material that follows is taken from the Supreme Court's opinion in Lucas, id., and therefore I have not cited matters that can be found in the Lucas opinion.

12. S.C. Code ANN. § 48-39-250-360 (Law. Co-op. Supp. 1992).

13. S.C. Code ANN. § 48-39-250 (Law. Co-op. Supp. 1992). 
taking of his property. Lucas, however, did not challenge the legislative findings that a ban on development was necessary to protect life and property against serious harm, nor did he question the validity of the Act as a lawful exercise of the police power. Instead, he asserted that since the Act completely extinguished his property's value, he was entitled to compensation. Lucas won in the trial court, which found that the ban had made Lucas' lots "valueless."14 The South Carolina Supreme Court, however, reversed. Since Lucas had not challenged the validity of the statute, the State Supreme Court accepted the legislative findings that the Act was designed to prevent serious harm and held that such a law did not constitute a compensable taking, despite the Act's impact on the property's value.

The United States Supreme Court granted Lucas' petition for certiorari ${ }^{15}$ on the question of whether complete elimination of value by a legislative act constituted a compensable taking, notwithstanding the purpose or validity of the legislation. In an opinion by Justice Scalia, a five member majority rejected Lucas' unqualified claim, but the Court articulated a special rule for cases of total deprivation of a property's economic value. The Court held that when legislation deprives an owner of all economic value in real property, compensation is required unless the planned development violates "restrictions that background principles of the State's law of property and nuisance already place upon land ownership." 16 Thus, the central question in these cases is whether the use restrictions were "part of [the landowner's] title to begin with."17 The Court remanded the case so that the South Carolina court could determine whether state common law had already proscribed Lucas' intended uses. The Court observed, however, that "[i]t seems unlikely that common-law principles would have prevented the erection of any habitable or productive improvements on [Lucas'] land."18

The Supreme Court viewed Lucas as an important case. Justice Scalia's opinion extensively reviewed property theory and takings jurisprudence. Justice Kennedy concurred with the majority but felt that it adopted an overly narrow view of police power. ${ }^{19}$ Justices Blackmun and Stevens each wrote dissents portraying the majority opinion as backward looking, inconsistent with precedent in the takings field, and insensitive to contemporary problems. ${ }^{20}$

On its face, Lucas is an odd decision. The opinion contains novel stan-

14. Lucas, 112 S. Ct. at 2890.

15. 112 S. Ct. 436 (1991).

16. Lucas, 112 S. Ct. at 2900.

17. Id. at 2899.

18. Id. at 2901 .

19. Justice Kennedy finds the case appropriate for decision but opines that "[t]he common law of nuisance is too narrow a confine for the exercise of regulatory power in a complex and interdependent society .... Coastal property may present such unique concerns for a fragile land system that the State can go further ... than the common law of nuisance might otherwise permit." Id. at 2903 (Kennedy, J., concurring).

20. Justices Blackmun and Stevens, in dissent, conclude that, pursuant to a 1990 Amendment to the Act, Lucas possibly could obtain a special permit to build. Therefore, the resulting possibility 
dards and unfamiliar formulations. ${ }^{21}$ For example, it distinguishes between land and personal property-a distinction the Court never previously made in takings cases. It employs the term "nuisance" in a novel way for the Court. ${ }^{22}$ The Court tosses aside the familiar harm/benefit distinction. ${ }^{23}$ The opinion speaks mysteriously of "the historical compact recorded in the Takings Clause that has become part of our constitutional culture,"24 without further explanation. Most peculiarly, while Lucas purports to articulate an important constitutional standard, the Court applies its ruling only to cases of total economic loss, conceding that those cases are "relatively rare."25 As Justice Scalia acknowledges, a distinction between a 100 percent loss and a 95 percent loss seems arbitrary in the context of constitutional rights. ${ }^{26}$ These oddities are explained by the Court's underlying agenda. In the pages that follow, I shall try to describe this agenda and explain why I believe it goes astray.

of no actual loss for any temporary taking between 1988 and 1990 counseled against deciding the case. Id. at 2906-08 (Blackmun, J., dissenting); id. at 2917-18 (Stevens, J., dissenting).

Justice Souter neither concurs nor dissents but writes that the Court should not have granted the writ. Because he felt there was an inadequate predicate for the assumption that Lucas' property had been made valueless, Souter argued that the writ of certiorari should have been dismissed. Id. at 2925 (Statement of Souter, J., arguing for dismissal of certiorari).

21. However, the doctrinal shape of the majority opinion in Lucas was foreshadowed in some respects by Agins v. City of Tiburon, 447 U.S. 255, 260 (1980) (stating in dictum that a statute regulating land effects a taking if it "denies an owner economically viable use of his land"), by Justice Scalia's comments in Nollan v. California Coastal Comm'n, 483 U.S. 825, 834 n.2 (1987) (analyzing the harm/benefit distinction), and by Chief Justice Rehnquist's dissents in both Keystone Bituminous Coal Ass'n v. DeBenedictis, 480 U.S. 470, 506 (1987) (Rehnquist, C.J., dissenting), and Penn Cent. Transp. Co. v. New York City, 438 U.S. 104, 145 (1978) (Rehnquist, C.J., dissenting) (citing the nuisance exception).

22. Justice Scalia adopts a historical definition of nuisance: One must identify the regulation as being the sort that would have supported a common law nuisance action. Lucas, 112 S. Ct. at 290002. Although Scalia admits that new knowledge which deals with traditional concerns, such as safety, may justify a new subject of regulation-citing the example of a nuclear plant located on an earthquake fault-he does not explain how tightly history constrains his rule. Id. at 2900 . Older Supreme Court opinions took a broader view of "nuisance" in upholding regulations which were directed at conduct that had only recently been deemed undesirable. For example, the conduct proscribed by the alcohol prohibition law which was sustained in Mugler v. Kansas, 123 U.S. 623 (1887), would not have been enjoined as a common law nuisance. The same is probably true of each of the "nuisance" cases Justice Scalia cites. Lucas, 112 S. Ct. at 2897.

23. Lucas, $112 \mathrm{~S}$. Ct. at 2898. Justice Scalia's opinion in Nollan v. California Coastal Comm'n, 483 U.S. 825 (1987), anticipated his discussion of the harm/benefit distinction in Lucas. In Nollan, he said that the right to build on one's own property could not be described as a "government benefit." Id. at 834 n.2.

24. Lucas, 112 S. Ct. at 2900.

25. Id. at 2894 . While in recent years the Court has frequently indicated that a regulation that denies all economicaily beneficial use is a taking, see id. at 2893, it has not previously found a taking solely on that ground. The only exception is Pennsylvania Coal Co. v. Mahon, 260 U.S. 393 (1922), an unusual case in which the coal company had effectively bought the right to create subsidence, only to have that right later taken away by regulation, a circumstance the Court viewed with obvious disapproval.

26. Lucas, 112 S. Ct. at 2895 n.8. 


\section{UNDERSTANDING LUCAS}

\section{A. Where the Court Stands}

On reflection, I do not find the Court's handling of Lucas and the Term's other takings cases as baffling as it first appears. On one level, the cases demonstrate that the current Court takes property rights seriously, believes government abuse of regulatory power is a problem, and feels the takings issue has been ignored too long by the Supreme Court. The Court, however, shows no taste for overturning the vast structure of regulatory government, ranging from billboards to bank failures. Its bent is conservative rather than libertarian. ${ }^{27}$ Moreover, it recognizes the difficulty of selectively entering the regulatory maze. For example, while rent control is among the most criticized forms of economic regulation, as a constitutional matter it cannot easily be distinguished from a multitude of other, far more familiar, adjustments of market economic relations between landlords and tenantssuch as laws requiring heat or adherence to minimal safety standards. ${ }^{28}$

On another level, I suspect the Court is frustrated with the takings issue. It wants to affirm the importance of property, but it cannot find a standard that will control regulatory excess without threatening to bring down the whole regulatory apparatus of the modern state. This difficulty may explain the fate of most of the 1992 takings cases. The same problem may explain Justice Scalia's taste for a "categorical" approach, seizing on clear (if formalistic) measures, such as physical invasion or diminution of value, before providing compensation. ${ }^{29}$ However inadequate such standards may be, they do provide the Court with some means to address property claims and to respond to the most extreme state intrusions-interference with possession or total loss of value. In addition, the Court may sense that by granting review of some takings cases, and only dealing with those that seem to involve excess, it conveys a message to regulators to withdraw from the frontiers and follow more conventional modes of regulation. ${ }^{30}$

\section{B. What Lucas Means}

If I am correct in suggesting that the current Court intends to play a restrained role in the property area, how is Justice Scalia's aggressive opinion in Lucas to be understood? The case is not as far reaching as its rhetoric suggests. It does not protect all who suffer a complete loss in their prop-

27. See Joseph L. Sax, Property Rights in the U.S. Supreme Court, A Status Report, 7 UCLA J. ENVTL. L. \& PoL'y 139, 150 (1988). The new Court has not overturned any significant state or federal regulatory program on takings grounds.

28. In Pennell v. City of San Jose, 485 U.S. 1 (1988), the Court indicated that it had no inclination to treat rent control itself as a taking.

29. Lucas, 112 S. Ct. at 2893-95. The physical invasion standard set out in Loretto v. Teleprompter Manhattan CATV Corp., 458 U.S. 419 (1982), is also a categorical standard.

30. The temporary takings doctrine articulated in First English Evangelical Lutheran Church v. County of Los Angeles, 482 U.S. 304 (1987), assures that local governments take the Court's hovering presence seriously: The doctrine requires compensation for the period during which the invalid regulations were in force, rather than only requiring a prospective repeal. 
erty's value, for the categorical 100 percent diminution rule itself is sharply limited. Regulation that would be sustained under established common law "principles" of nuisance and property law is not affected. Presumably, states will have substantial latitude in determining the extent to which their existing legal principles limit property rights. ${ }^{31}$ Moreover, Justice Scalia is careful to provide assurance that Lucas is not a threat to conventional industrial regulation, including environmental laws such as those dealing with pollution or toxics disposal. ${ }^{32}$ Thus, despite its tone, Lucas appears consistent with the restraint the Court has generally exercised in takings cases. ${ }^{33}$

What, then, is the majority's agenda in the Lucas case? I believe Justice Scalia felt that the case presented a new, fundamental issue in property law, and that he had a clear message which he sought to convey: States may not regulate land use solely by requiring landowners to maintain their property in its natural state as part of a functioning ecosystem, even though those natural functions may be important to the ecosystem. ${ }^{34}$ In this sense, while the Lucas majority recognizes the emerging view of land as a part of an ecosystem, rather than as purely private property, the Court seeks to limit the legal foundation for such a conception.

Lucas may thus be viewed as the Court's long-delayed answer to the decision by the Wisconsin Supreme Court in Just v. Marinette County, ${ }^{35}$ one

31. However, the Supreme Court does not defer entirely to state court interpretations of state law. See Webb's Fabulous Pharmacies, Inc. v. Beckwith, 449 U.S. 155, 164 (1980); PruneYard Shopping Ctr. v. Robins, 447 U.S. 74, 83-84 (1980); Duke Power Co. v. Carolina Envtl. Study Group, Inc., 438 U.S. 59, 88 (1978); Hughes v. Washington, 389 U.S. 290, 296 (1967) (Stewart, J., concurring).

32. The Lucas majority indicates that it does not intend to undercut the existing scope of regulatory government:

It seems to us that the property owner necessarily expects the uses of his property to be restricted, from time to time, by various measures newly enacted by the State in legitimate exercise of its police powers .... And in the case of personal property, by reason of the State's traditionally high degree of control over commercial dealings, he ought to be aware of the possibility that new regulation might even render his property economically worthless....

$112 \mathrm{~S}$. Ct. at 2899 . While singling out personal property is novel, I am confident, for reasons I shall spell out, that this passage is not meant as a threat to established land use regulation any more than it is to industrial regulation.

33. The Court may be seeking to put a greater burden on government to justify its regulatory laws. This is one of Justice Blackmun's concerns. He fears that the majority is overturning the presumption of constitutionality. I believe that courts will continue to be deferential in the great majority of cases and that they can do so while still dealing with abuses of power or significant discrepancies between problem and remedy. See text accompanying notes 99-103 infra. As suggested earlier, the Court may be pressing local governments to withdraw from the regulatory frontier. To be sure, the Supreme Court's strong rhetoric may embolden some lower courts to strike down conventional regulation, but the Court's recognition of the dangers of unraveling a central structure of modern government (i.e. regulation of the economy) suggests that no radical change is on the horizon.

34. Several recent articles have discussed the challenges that ecological theory presents to conventional property theory, sometimes characterizing the challenge as a philosophical one against a view that "presupposes mankind's moral domination over creation," Peter J. Byrne, Green Property, 7 CONST. COMMENTARY 239, 247 (1990), and sometimes suggesting that the challenge is a scientific one, David B. Hunter, An Ecological Perspective on Property: A Call for Judicial Protection of the Public's Interest in Environmentally Critical Resources, 12 HARV. ENVTL. L. REV. 311 (1988).

35. 56 Wis. $2 d 7,201$ N.W.2d 761 (1972). Wisconsin itself may have moved away from the 
of the cases that launched the modern era of environmental law:

An owner of land has no absolute and unlimited right to change the essential natural character of his land so as to use it for a purpose for which it was unsuited in its natural state and which injures the rights of others. The exercise of the police power in zoning must be reasonable and we think it is not an unreasonable exercise of [the police] power to prevent harm to public rights by limiting the use of private property to its natural uses. ${ }^{36}$

The target of Lucas is broader than its immediate concern of coastal dune maintenance; the opinion encompasses such matters as wetlands regulation, which recently has generated a great deal of controversial litigation. ${ }^{37}$ Lucas also anticipates cases that will be brought under section nine of the Endangered Species Act, under which private landowners may be required to leave their land undisturbed as habitat. ${ }^{38}$ In general, Lucas addresses legislation imposed to maintain ecological services performed by land in its natural state. The Court correctly perceives that an ecological worldview presents a fundamental challenge to established property rights, but the Court incorrectly rejects that challenge.

To appreciate the significance of Lucas, it is necessary to understand how the majority interpreted the intent of the South Carolina law. The statute was so broadly drawn that it could be viewed as having a number of purposes. South Carolina might have intended to prohibit construction in a hazardous zone because of the resulting dangers to others and the inevitable burden which would be imposed on the state in the event of a catastrophic event such as a hurricane or an earthquake. Although the Court doubts that this was the actual purpose of the South Carolina law, the Lucas opinion makes clear that such a purpose could be implemented through noncompensable regulation. ${ }^{39}$

Alternatively, South Carolina may have designed the statute to ensure that beaches were left undeveloped in order to preserve a visual amenity for tourists. If so, the Court would surely have viewed the case as the compen-

most extreme implications of Just. See Kmiec v. Town of Spider Lake, 60 Wis. 2d 640, 211 N.W.2d 471 (1973) (holding that a zoning classification that gave land negative value had no reasonable basis and was therefore unconstitutional).

36. 201 N.W.2d at 768.

37. See, e.g., Florida Rock Indus. v. United States, 23 Cl. Ct. 653 (1991); Loveladies Harbor, Inc. v. United States, 21 Cl. Ct. 153 (1990); see also Lucas, 112 S. Ct. at 2898 (referring to wetlands cases). Such cases have been controversial for decades. See, e.g., MacGibbon v. Board of Appeals, 356 Mass. 635, 255 N.E.2d 347 (1970); Joseph L. Sax, Takings, Private Property and Public Rights, 81 YALE L.J. 149, 159-60 \& n.28 (1971). Regulations requiring landowners to maintain property which is subject to flooding as water retention basins present analogous problems. See, e.g., Dooley v. Town Plan \& Zoning Comm'n, 151 Conn. 304, 197 A.2d 770 (1964).

38. Endangered Species Act, 16 U.S.C. $\S \S 1532(19)$, 1538(a) (1988). The statute prohibits "taking" endangered species, which is defined to include "harm[ing]" them. Regulations under the Act, 50 C.F.R. \$ 17.3 (1991), define harm to "include significant habitat modification." Thus development of land that is a critical habitat for an endangered species can be an unlawful taking of the species under the Act. See Palila v. Hawaii Dep't of Land \& Natural Resources, 639 F.2d 495 (9th Cir. 1981).

39. The Court indicates that regulation of a nuclear plant on an earthquake fault is an example of safety-oriented legislation-valid because it regulates conduct that "was always unlawful." Lucas, 112 S. Ct. at 2900-01 (emphasis omitted). 
sable taking of a visual easement, similar to a nondevelopment easement alongside a scenic highway. The majority implies that it thinks that this was probably the actual purpose of the regulation. ${ }^{40}$

If the Beachfront Management Act's purpose were only one of the above two alternatives, Lucas would be of little consequence. Instead, a third possible interpretation exists, and the Court's response to it invests the decision with fundamental importance. This interpretation also clarifies Justice Scalia's otherwise perplexing majority opinion. The regulation might have arisen from a determination that Lucas' property-coastal dune land-was performing an important ecological service to uplands by functioning as a storm and erosion barrier. Therefore, maintenance of the land in its natural condition might have been ecologically necessary. Justice Scalia is clearly skeptical that such an ecological purpose underlay the regulation. ${ }^{41} \mathrm{He}$ explicitly noted that the articulation of an ecological purpose could be a guise for expropriation of a public easement. 42

Most importantly, however, Justice Scalia concludes that even if the statute were motivated by an important ecological purpose, South Carolina would have to compensate Lucas, since landowners are not required to accede to restrictions of that genre under existing "background principles" of law. ${ }^{43}$ In this light, whether or not maintaining ecological functions were the primary purpose of the South Carolina law, Justice Scalia viewed Lucas as a potential precedent for cases where regulations premised on maintenance of natural function diminished the value of private property. ${ }^{44}$ If the South Carolina regulation had been sustained, the decision would have constitutionalized a broad panoply of laws requiring landowners to leave their property in its natural condition. The opinion recognizes that, in the name of environmental protection, an entirely new sort of regulation could be imposed. To prevent such a result, the Court repudiates the conclusion of Just, and instead effectively reverses the Wisconsin court's conclusion that "it is not an unreasonable exercise of [police] power to prevent harm to public rights by limiting the use of private property to its natural uses." 45

\section{Lucas' Doctrinal Peculiarities Support the Majority's Purpose}

The Lucas majority may have designed the seemingly odd ruling to isolate the ecological regulations which Justice Scalia seeks to illegitimate,

40. This seems to be what Justice Scalia has in mind when he speaks of land "being pressed into some form of public service under the guise of mitigating serious public harm," while referring to Annicelli v. Town of South Kingstown, 463 A.2d 133 (R.I. 1983), a case that considered regulations prohibiting construction adjacent to a beach. Lucas, $112 \mathrm{~S}$. Ct. at 2895.

41. Lucas, $112 \mathrm{~S}$. Ct. at $2898 \mathrm{n} .11$ (commenting tartly on the fact that existing structures are permitted to remain and that variances were permitted under a new amendment to allow construction).

42. Id. at $2894-95$.

43. Id. at 2900 .

44. Scalia's citation to Annicelli suggests his awareness of "the role barrier beaches play in the ecological system." 463 A.2d at 137. That ecological role is described explicitly in Annicelli. Id.

45. Just v. Marinette County, 201 N.W.2d 761, 768 (Wis. 1972). 
without jeopardizing mainstream regulations. The majority's nuisance exception illustrates this point. Justice Scalia surely knows that nuisance law is a slippery legal concept-it has been applied to everything from brothels ${ }^{46}$ to bowling on Sundays. ${ }^{47}$ His use of nuisance law, however, is neither stupid nor careless. He invokes nuisance principles to emphasize the difference between regulations which are designed to maintain land in its natural condition and regulations which embrace conventional police power. ${ }^{48}$ Rather than describe how property may be used-which is the traditional function of nuisance law-this new sort of environmental regulation effectively determines whether property may be used at all. Traditional nuisance law, however broadly construed, limited use. Its protection was wide-ranging, but it did not characterize property as having inherent public attributes which always trump the landowner's rights. This traditional understanding of private property is presumably what Justice Scalia feels is embedded in our "constitutional culture." 49 In this sense, laws demanding that landowners maintain the natural conditions of their property transgress even the most broadly construed "background principles of nuisance and property law."50

Justice Scalia's view of traditional private property principles also explains his rejection of a harm/benefit distinction ${ }^{51}$ and his recognition that landowners have positive development rights. From a certain environmental perspective, making places less natural is itself "harmful." If transformation to human use is itself defined as harmful, many land uses which were previously legitimate could become unlawful. This concern leads Justice Scalia to shift from a conception of property rights that defines what owners cannot do ("harm" to others) to what they can do (develop land to produce private economic return). Ownership is thereby redefined as some irreducible right of use by the private landowner. Ownership then means at least that the owner has some right to employ the property for personal benefit, even if it thereby eliminates "benefits" that land provides in its natural state.

Read this way, Justice Scalia's opinion emphasizes four points: (1) leaving land in its natural condition is in fundamental tension with the traditional goals of private property law; (2) once natural conditions are considered the baseline, any departure from them can be viewed as "harmful," since the essence of human use of land is interrupting the land's natural state; (3) if any disruption of natural conditions can be viewed as harmful (as

46. See, e.g., City of Chicago v. Festival Theatre Corp., 91 Ill. 2d 295, 304-05, 438 N.E.2d 159, 163 (1982).

47. See City of Shreveport v. Leiderkrantz Soc'y, 130 La. 802, 58 So. 578 (1912).

48. The peculiar distinction drawn between land and what the Court calls personal property seems to have the same goal. See Lucas, 112 S. Ct. at 2899-90. When government regulates factories, pesticides, or automobiles, it deals with the products of human development. Only when it regulates land does maintenance of the state of nature become an issue. While all cases demanding maintenance of natural conditions involve land, not all land cases involve maintenance of natural conditions (e.g., routine zoning). Thus, the distinction drawn between land and personal property is one of the opinion's least artful efforts. Nonetheless the majority's purpose seems clear.

49. Id. at 2900 .

50. Id. at 2901.

51. Id. at $2897-99$. 
surely they can), then natural conditions generally could be viewed as normal and could be demanded by the state; and (4) with that predicate, states could exercise their police power to maintain natural conditions, thereby eliminating the economic value of private property to its owner.

Justice Scalia's opinion raises two important questions. Are environmental regulations that require maintenance of natural conditions significantly new and different from traditional regulations? If so, how should the law respond?

\section{The Deeper Meaning of Lucas: Property IN THE TWO ECONOMIES}

There are two fundamentally different views of property rights to which I shall refer as land in the "transformative economy" and land in the "economy of nature." 52 The conventional perspective of private property, the transformative economy, builds on the image of property as a discrete entity that can be made one's own by working it and transforming it into a human artifact. A piece of iron becomes an anvil, a tree becomes lumber, and a forest becomes a farm. Traditional property law treats undeveloped land as essentially inert. The land is there, it may have things on or in it (e.g., timber or coal), but it is in a passive state, waiting to be put to use. Insofar as land is "doing" something-for example, harboring wild animals-property law considers such functions expendable. Indeed, getting rid of the natural, or at least domesticating it, was a primary task of the European settlers of North America.

An ecological view of property, the economy of nature, is fundamentally different. Land is not a passive entity waiting to be transformed by its landowner. Nor is the world comprised of distinct tracts of land, separate pieces independent of each other. Rather, an ecological perspective views land as consisting of systems defined by their function, not by man-made boundaries. Land is already at work, performing important services in its unaltered state. For example, forests regulate the global climate, marshes sustain marine fisheries, and prairie grass holds the soil in place. Transformation diminishes the functioning of this economy and, in fact, is at odds with it.

The ecological perspective is founded on an economy of nature, while the transformative economy has a technological perspective of land as the product of human effort. As Philip Fisher states in Making and Effacing Art:

At the center of technology is the human act of taking power over the world, ending the existence of nature; or, rather, bracketing nature as one component of the productive total system. The world is submitted to an inventory that analyzes it into an array of stocks and resources that can be moved from place to place, broken down through fire and force, and assem-

52. Several recent books employ the idea of a natural economy. See, e.g., RoBERT E. Ricklefs, THE ECONOMY Of NATURE: A TEXTBOOK IN BASIC Ecology (1976); Donald WoRSTER, NATURE's ECONOMY: A History OF ECOLOGICAL IDEAS (1985). 
bled through human decisions into a new object-world, the result of work. ${ }^{53}$

For most of the modern era, the technological use of land has operated to end "the existence of nature." Land has been fenced, excluding wildlife so that it could instead support domesticated grazing animals, agriculture, and human settlements. As William Cronon has shown, a natural subsistence economy that supported indigenous people was systematically replaced by the farming and commercial economy of the European settlers. ${ }^{54}$ The property system was a central tool in effecting this transformation. The tension between Native Americans and the European settlers was a "struggle ... over two ways of living . . . and it expressed itself in how two peoples conceived of property, wealth, and boundaries on the landscape."ss The settlers' property system invested proprietors with the right to sever natural systems to turn land to "productive" use. Thus, the transformative economy was built on the eradication of the economy of nature.

Even when people acknowledged the toll of development on natural resources, giving birth to the conservation movement in the nineteenth century, there was virtually no impact on the precepts of property law. The concerns of conservation were then largely aesthetic, and ecological understanding was limited. Exceptions existed, ${ }^{56}$ especially in understanding the adverse impact of timber harvesting on watersheds, but even as to forests, conservation was largely implemented on distant lands where public ownership prevailed. The principal aim of the early conservation movement was to set aside remote enclaves as public parks, forests, and wildlife refuges,

53. Philip Fisher, Making and Effacing ARt: Modern American ARt in a Culture OF MUSEUMS 223 (1991).

54. William Cronon, Changes in the Land: Indians, Colonists, and the Ecology OF NEW ENGLAND 54-81 (1983).

55. Id. at 53 .

56. As early as 1769 , French law on the island of Mauritius required that " 25 percent of all landholdings ... be kept as forest, particularly on steep mountain slopes, to prevent soil erosion; all denuded areas ... be reforested; and all forests within 200 yards of water ... be protected." Richard H. Grove, Origins of Western Environmentalism, SCI. AM., July 1992, at 42, 44.

Sometimes enclaves were employed as part of a scientific strategy. Grove indicates that a percentage of all forested land in Tobago was set aside as "rain reserves" in the eighteenth century. Id. at 45 . But such measures were unusual. The call for ecologically based land use regulation almost always went unheeded. Perhaps the most notable American case was John Wesley Powell's prescient but ignored plea for western developers to consider the effects of aridity. See J.W. PowELL, REPORT ON THE LANDS OF THE ARID REgION OF THE UNITED STATES, WITH A MORE DETAILED Account of the LaNDS of Utah 37-57 (Wallace Stenger ed., Belknap Press of Harvard University Press 1962) (1878).

George Perkins Marsh voiced another rare and unheeded call for an ecological perspective in land management. Marsh wrote:

In countries untrodden by man ... the atmospheric precipitation and evaporation, the thermometric mean, and the distribution of vegetable and animal life, are subject to change only from geological influences so slow in their operation that the geographical conditions may be regarded as constant and immutable. These arrangements of nature it is, in most cases, highly desirable substantially to maintain, when such regions become the seat of organized commonwealths.

George Perkins Marsh, Man and NAture 35 (David Lowenthal ed., John Harvard Library, Harvard University Press 1967) (1864) (emphasis added). 
where nature could be preserved while elsewhere the transforming business of society went on as usual.

The burst of concern for controlling industrial pollution also failed to propel nature's economy onto the legal agenda. Conventional pollution laws do not challenge the traditional property system. They do not demand that adjacent land be treated as part of a river's riparian zone nor that it be left to perform natural functions supportive of the river as a marine ecosystem. On the contrary, such laws assume that a river and its adjacent tracts of land are separate entities and that the essential purpose of property law is to maintain their separateness. Thus, they assume development of the land and internalization of the development's effects; they are effectively "no dumping" laws, under which the land and the river are discrete entities.

Benefits that adjacent lands and waters confer upon each other can, with rare exceptions, be terminated at the will of the landowner, because the ecological contributions of adjacent properties are generally disregarded in defining legal rights. For example, if riparian uplands are the habitat for river creatures that come on shore to lay their eggs, landowners are perfectly free to destroy that habitat while putting the land to private use-even though doing so harms the river and its marine life. The existence of such connections between property units was not unknown (though certainly much more is currently known about their importance); rather, until recently society assumed that the termination of natural systems in favor of systems created by human effort was a change for the better. In addition, when significant ecological losses did occur, people believed that the losses could be compensated through technological means. Therefore, landowners developed upstream lands that, in their natural state, had absorbed flood waters. ${ }^{57}$ The adverse effects of too much waterflow on downstream lands were either tolerated or replaced technologically, as with flood control dams. Finally, when dams were built, states tried to replace instream losses with fish hatcheries.

Although these differences between the attitudes of the two economies are easy to distinguish in theory, no absolutely firm lines of demarcation exist in either historical experience or legal regimes. Certainly some ecological functions have been recognized and protected by the law. For example, lands adjacent to refuges have been closed to hunting in recognition of the habitat that the land provides for migrating birds. 58 Many situations, however, cannot be definitively categorized as premised on the transformational economy or the economy of nature. In addition, a restriction might serve two quite different functions. For example, timber harvesting near a river's edge is sometimes regulated to prevent siltation of the river. ${ }^{59}$ Such regulation might be viewed as either a protection of natural transboundary services, with trees holding soil in place, or an anti-dumping law, where the

57. E.g., Dooley v. Town Plan \& Zoning Comm'n, 151 Conn. 304, 197 A.2d 770 (1964).

58. See Bailey v. Holland, 126 F.2d 317 (4th Cir. 1942).

59. See National Wildlife Fed'n v. United States Forest Serv., 592 F. Supp. 931, 934, 942-43

(D. Or. 1984) (considering effect of timber harvesting on watershed area). 
migration of soil is treated as a consequence of the harvesting, tantamount to a forester jettisoning soil into the river. Similarly, a restriction on building in a flood plain might be viewed as a demand of the economy of nature, preserving the habitat of the protected area, or as a restriction designed to promote human safety by keeping workers and residences out of a hazardous area in the event of a storm. ${ }^{60}$ In the same manner, the maintenance of open space could be characterized as either a service in the economy of nature or a limitation on transformation, guided by congestion concerns or aesthetic preferences. These restrictions defy easy classification, but ultimately, for purposes of this analysis, no such classification is needed. It is only necessary to acknowledge the existence of two very different views of what land is and what purposes each view serves.

Viewing land through the lens of nature's economy reduces the significance of property lines. Thus a wetland would be an adjunct of a river, in service to the river as a natural resource. Beach dune land would be the frontal region of a coastal ecosystem extending far beyond the beach itself. A forest would be a habitat for birds and wildlife, rather than simply a discrete tract of land containing the commodity timber. Under such a view the landowner cannot justify development by simply internalizing the effect of such development on other properties. Rather, the landowner's desire to do anything at all creates a problem, because any development affects the delicate ecosystem which the untouched land supports. In an economy of nature the landowner's role is perforce custodial at the outset, before the owner ever transforms the land. Moreover, the object of the custody generally extends beyond the owner's legally defined dominion. The notion that land is solely the owner's property, to develop as the owner pleases, is unacceptable.

This emerging ecological view generates not only a different sense of the appropriate level of development, but also a different attitude towards land and the nature of land ownership itself. The differences might be summarized as follows:

\section{TRANSFORMATIVE ECONOMY}

Tracts are separate. Boundary lines are crucial.

Land is inert/waiting; it is a subject of its owner's dominion.

Land use is governed by private will; any tract can be made into anything. All land is equal in use rights (Blackacre is any tract anywhere).

\section{ECONOMY OF NATURE}

Connections dominate. Ecological services determine land units.

Land is in service; it is part of a community where single ownership of an ecological service unit is rare.

Land use is governed by ecological needs; land has a destiny, a role to play. Use rights are determined by physical nature (wetland, coastal barrier, wildlife habitat).

60. Safety was the purpose of the building prohibition at issue in First English Evangelical Lutheran Church v. County of Los Angeles, 482 U.S. 304 (1987). 
Landowners have no obligations.

Land has a single (transformative) purpose.

The line between public and private is clear.
Landowners have a custodial, affirmative protective role for ecological functions.

Land has a dual purpose, both transformative and ecological.

The line between public and private is blurred where maintenance of ecological service is viewed as an owner's responsibility.

No matter whether these differences are characterized as qualitative or quantitative, the economy of nature greatly affects conceptions of owner entitlement-an issue that Justice Scalia correctly discerned beneath the surface of Lucas. ${ }^{61}$

Although the majority opinion recognizes the differences between a transformative economy and an economy of nature, it rejects the demands of the economy of nature as legitimate obligations of land and of landowners. As suggested above, all the seeming oddities of the opinion-the distinction between land and personal property, the total loss requirement, the novel nuisance test, the elimination of the harm/benefit distinction, the focus on historical use, and the requirement that restrictions be in the "title to begin with"- can best be viewed as doctrinal devices which separate the demands of the transformational economy from those of the economy of nature.

The majority opinion correctly recognizes that a fundamental redefinition of property was possible in Lucas. In this light, Lucas represents the Court's rejection of pleas to engraft the values of the economy of nature onto traditional notions of the rights of land ownership. Justice Scalia assumes that redefinition of property rights to accommodate ecosystem demands is not possible. The Court treats claims that land be left in its natural condition as unacceptable impositions on landowners. By characterizing the demands of the economy of nature as pressing "private property into some form of public service," 62 the Court fails to recognize that lands in a state of nature are already in public service but to a purpose that the Court is unwilling to acknowledge.

Given that the economy of nature is emerging as a prominent viewpoint, the Court should have asked whether notions of property law could be reformulated to accommodate ecological needs without impairing the necessary functions of the transformational economy.

\section{Property Definitions have Always Been Dynamic}

Historically, property definitions have continuously adjusted to reflect new economic and social structures, often to the disadvantage of existing owners:

61. Whether Lucas itself raised this issue depends on what the regulation was designed to accomplish, a matter that was not made clear in the South Carolina statute.

62. Lucas, 112 S. Ct. at 2895. 
Economic development was a primary objective of Americans in the nineteenth century, but steps to promote growth frequently clashed with the interests of particular property owners .... Americans, in J. Willard Hurst's phrase, preferred "property in motion or at risk rather than property secure and at rest." As a consequence, legislators and courts often compelled existing property arrangements to give way to new economic ventures and changed circumstances. ${ }^{63}$

Property law has always been functional, encouraging behavior compatible with contemporary goals of the economy. ${ }^{64}$ Indeed, it would be difficult to identify a time when a given community's property law encouraged behavior at odds with its social values. ${ }^{65}$ Colonial America distrusted competition and extensively regulated contractual freedom, including food prices, interest rates, and wages. But "[a]s their focus shifted from scarcity to opportunity, the colonists increasingly viewed commercial regulations as an impediment to growth." 66

The redefinition of property to make it functional has a very long history. Traditional customs impeded the introduction of capitalism by aristocrats and entrepreneurs. ${ }^{67}$ As Marc Bloch's classic study of French rural history explains, the destruction of common rights was a response to the perception that "the existence of commons and grazing rights made it too easy for small-holders and manual labourers to eke out a meager living, [and] encouraged them to live in 'idleness' when they might have hired themselves out to work on the great estates." 68

Examples of property law's adaptation to social changes abound. In a ruder world, nuisance law originally imposed unprecedented duties of neighborliness on owners' rights. ${ }^{69}$ The Kentucky Constitution once opined that "the right of the owner of a slave to such slave, and its increase, is the same,

63. JAMES W. Ely, JR., The Guardian OF Every OTHER Right: A CONSTITUTIONAL HisTORY OF PROPERTY RIGHTS 6 (1992) (citation omitted).

64. "Social needs are the essential life that give vitality to all legal institutes .... As for the property law, to say that social life creates it is a very great understatement of the intimacy of their relation." Francis S. Philbrick, Changing Conceptions of Property in Law, 86 U. PA. L. REv. 691, 694-95 (1938).

65.

It is self-evident that neither the things recognized as the objects of property rights nor the nature of these rights themselves could possibly be the same under a land economy of 1700 and our industrial economy of today. Property, in the layman's sense of things, has varied infinitely in character and content from century to century and from place to place.

Id. at 691; see also Richard R.B. Powell, The Relationship Between Property Rights and Civil Rights, 15 HASTINGS L.J. 135 (1963) (describing the redefinition of property rights in response to social concerns).

66. ELY, supra note 63, at 22.

67. See, e.g., Marc Bloch, French RuRal History: AN EsSay on its Basic CharacterISTICS 213-18 (1960); E.P. THOMPSON, WHIGS AND HUNTERS: THE ORIGIN OF THE BLACK ACT $109,239-40$ (1975).

68. BLoch, supra note 67 , at 220.

69. "The twelfth century assize of nuisance began the body of law which cuts down what the owner of Blackacre can do, in view of his duty of neighborliness." Powell, supra note 65, at 142-43 (citation omitted); see also William A. McRae, Jr., The Development of Nuisance in the Early Common Law, 1 U. FlA. L. REV. 27 (1948). 
and as inviolable as the right of the owner of any property whatever."70 In eighteenth century America, the states abolished feudal tenures, ${ }^{71}$ abrogated primogeniture and entails, ${ }^{72}$ ended imprisonment for debt, ${ }^{73}$ and significantly reduced rights of alienation, ${ }^{74}$ as well as dower and curtesy. ${ }^{75}$ In the nineteenth century, to promote industrialization by hydropower mills, courts redefined the traditional rights of natural flow in water established during a preindustrial economy. ${ }^{76}$ The rules changed again when log-floating became a necessary way to get lumber to markets. ${ }^{77}$ In the arid west, landowners' riparian rights were simply abolished because they were unsuited to the physical conditions of the area. ${ }^{78}$ As the status of women changed, laws abolished husbands' property rights in their wives' estates. ${ }^{79}$

70. KY. CONST. OF 1850 , art. XIII, § 3. Interestingly, during the abolition of slavery in America-a movement that certainly grew out of a fundamental change in societal values-great deference was shown to slaveholders' property interests, perhaps in recognition of the issue's political sensitivity. "For example, Pennsylvania's 1780 emancipation statute applied only to future generations of slaves .... Even then, the law postponed freedom until such slave children reached the age of twenty-eight, in order to reimburse their masters for the expenses of raising them." ELY, supra note 63 , at 24 . Lincoln originally favored emancipation with compensation, and owners were compensated in 1862 when Congress abolished slavery in the District of Columbia. Of course, the Thirteenth Amendment later eliminated slavery without compensation to owners. Id. at 83. (1924).

71. William R. Vance, The Quest for Tenure in the United States, 33 YALE L.J. 248, 249

72. Richard B. MORRIS, STUdies IN THE History OF AMERICAN LAW 76-82, 86-92 (1930).

73. See Sturges v. Crowinshield, 17 U.S. (4 Wheat.) 122 (1819) (justifying abolition as not violating property rights).

74. Powell, supra note 65 , at 140 (citing the rule against perpetuities, unlawful restraints on alienation, bars against anti-social dispositions, and insistence upon formalities in dispositions). On a larger canvas, it has been observed that "with the rarest exceptions primitive people consider land inalienable." RoBerT H. LOWIE, AN INTRODUCTION TO CULTURAL ANTHROPOLOGY 153 (1934). The disappearance of that constraint is one of the greatest changes ever made in property theory, and its pains are still being felt by aboriginal people. See ThOMAS R. BERGER, VILLAGE JourNeY: THE REPORT OF THE ALASKA NATIVE REVIEw COMMISSION 73-95 (1985) (discussing the reaction of native people to the Alaska land settlement legislation).

75. See, e.g., Ferry v. Spokane, P. \& S. Ry., 258 U.S. 314 (1922); Randall v. Kreiger, 90 U.S. 137, 148 (1874) (sustaining the abolition of dower against a takings claim). Dower was abolished because it was a clog on transactions and was replaced largely by rights against the deceased husband's will. Consequently, it did not have the same powerful redistributional and status-changing significance as did the married women's property acts. See note 79 infra.

76. The historic evolution of riparian rights is traced in JOSEPH L. SAX, ROBERT H. ABRAMS \& BARTON H. THOMPSON, JR., LEgAL CONTROL OF WATER RESOURCES 69-87 (2d ed. 1991).

77. See Tyler v. Wilkinson, 24 F. Cas. 472 (C.C.D.R.I. 1827) (No. 14,312); Lancey v. Clifford, $54 \mathrm{Me} .487,491$ (1867).

78. E.g., Yunker v. Nichols, 1 Colo. 551 (1872).

79. E.g., Warburton v. White, 176 U.S. 484 (1899); Baker's Ex'rs v. Kilgore, 145 U.S. 487 (1892) (rejecting claims that married women's property laws took the property of husbands). In these cases, the Court indicated that the interest abolished was not a property right constitutionally protected against legislative modification or abolition. Such views are not surprising, since the redefinition of property rights is a historical reality that courts almost never explicitly recognize. A rare exception was the abolition of riparian rights in the arid West, justified by the law of "imperative necessity." See Coffin v. Left Hand Ditch Co., 6 Colo. 443, 449 (1882); see also Yunker, 1 Colo. at 551.

Certainly the husband's interest was valuable and provided a basis for economic dealings and expectations. At common law, the wife's lands were subject to the husband's right to take the rents and profits during the marriage and to sell his interest in his wife's land without her consent. Charles Donahue, Jr., What Causes Fundamental Legal Ideas? Marital Property in England and France in the Thirteenth Century, 78 Micr. L. REv. 59, 65 (1979). 
The modern company town and the modern shopping center have generated modifications to the law of trespass. ${ }^{80}$ In response to urbanization, legislative zoning reduced the rights of landowners. The affected landowners contested zoning statutes, claiming they were subject only to case-by-case restrictions on land use under nuisance law. The Supreme Court rejected their claim and validated zoning. Justice Sutherland wrote: "In a changing world, it is impossible that it should be otherwise." 81 Indeed, the very heart of the Lucas opinion-the concept that property ownership confers positive developmental rights-is a product of a modern economy that itself destroyed common rights in property because such rights were no longer functional in a capitalist society. ${ }^{82}$

\section{IS COMPENSATION THE ANSWER?}

Though the Lucas majority does not say so explicitly, its adoption of a standard based upon historically bounded nuisance and property law reflects a sentiment that a state should compensate landowners who, through no fault of their own, lose property rights because of scientific or social transformations. The Lucas opinion focuses on landowners-such as proprietors of barrier beaches or wetlands-who seem to be the ultimate victims of unanticipated, uncontrollable changes. Not only are their land uses restricted for historically unrecognized purposes, but also they own a type of land that, by today's standards, should never have been subject to private ownership at all.

In the past, innocent loss in the face of unexpected change did not generate a right of compensation. Most owners regulated under new laws were hapless victims of changes they could not reasonably have anticipated. Farmers could not have known that the pesticides they were using were harmful; industrialists located on rivers could not have anticipated modern water pollution laws; buyers of land now deemed unstable did not have the advantage of modern methods for detecting instability. Paradoxically the most unexpected and sweeping changes, such as the industrial revolution, left the largest number of uncompensated victims in their wake. Notions of "expectation" or the "principles" of nuisance law cannot explain the failure to compensate such owners. Why they were left to bear their losses is a profoundly interesting question.

The noncompensation norm in circumstances of social change reflects a decision to encourage adaptive behavior by rewarding individuals who most adroitly adjust in the face of change. Understanding attitudes about change and adaptability reveals the rationale behind legal compensation rules. These attitudes probably explain a good deal more than an attempt to elicit

80. PruneYard Shopping Ctr. v. Robins, 447 U.S. 74, 82 (1980) (access to modern shopping center); Marsh v. Alabama, 326 U.S. 501 (1946) (access to company town); see also State v. Shack, 58 N.J. 297, 277 A.2d 369 (1971) (access to migratory farm workers on employer's land).

81. Village of Euclid v. Ambler Realty Co., 272 U.S. 365, 387 (1926).

82. See Forrest MCDOnald, Novus Ordo Seclorum: The INTEllectual Origins of THE CONSTITUTION 30 n.27 (1985). 
some deep meaning from concepts like "nuisance" or "expectations." As existing uses are granted the status of compensable property rights, change becomes less desirable. A society which values change will also likely value human adaptability.

Rather than compensate all the owners disadvantaged by the industrial revolution, for example, property rules changed to promote and encourage development. The courts encouraged the process of industrialization by refraining from socializing its costs through compensation; society rewarded those owners who were best able to respond to the changing world. Noncompensation thereby promoted technological and economic innovation.

Society expected the displaced landed gentry to find its place in a new, industrialized world; villagers were expected to learn to live in an urban environment. No one could assert a right to be insulated from losses due to the changes effected by coal mines and nearby railroads. Later, people had to learn to live without child labor, indentured servants, and women simply as houseworkers.

In a more modern context, businesses have learned to thrive in an atmosphere of taxes and regulation. Those that have survived under regulation may have to adapt again when deregulation (or the end of a guild system) becomes the order of the day. Today, many owners possess fragile lands, asbestos mines, or contaminated lands. All such owners are, in a sense, the victims of a changing world. If society puts a premium on adaptability, then, during periods of change, the most adaptive owners will lose the least.

Many forms of adaptive behavior mediate the competing demands of the transformational economy and the economy of nature. Some are already familiar, such as contour plowing to prevent erosion and the clustering of subdivision developments to preserve wooded areas which provide wildlife habitat, windbreaks, and soil stability. Other, less familiar forms of adaptation exist as well. Diversification and timely divestment of lands unsuitable for development are techniques of economic adaptation. Similarly, the acquisition of tracts that are sufficiently large could make it economically feasible to preserve some land in its natural state, while other areas could be developed more intensely. ${ }^{83}$ Pooling several people's resources to achieve joint management and shared profits could assure that not every acre a person owns would have to be transformed from its natural state. Such arrangements could provide alternatives to the Lucas majority's concerns about total economic loss. In such cases the whole might be as valuable as the pieces would have been if developed by conventional means. The loss to

83. Recently enacted provisions of CAL. FISH \& GAME CODE $\S \S 2805,2810$ (West Supp. 1993) encourage such arrangements. They authorize the Department of Fish and Game to enter into a voluntary "natural community conservation plan" with landowners. The plans are to provide for the protection and perpetuation of natural wildlife diversity, while allowing compatible and appropriate development and growth. See also Southview Assocs. v. Bongartz, 900 F.2d 84, 92 (2d Cir. 1992) (holding applicant for development permit should develop other parts of its 88.5 acre property to lessen impact on deer habitat). 
areas left undeveloped might be compensated by enhanced value in open space or the presence of wildlife, good fishing, and recreation.

Such opportunities will not be available in every situation. Certain individuals will inevitably be caught up in the transitional moment. These first owners to whom the new rule applies will have no opportunity to respond adaptively. At some level the problem is inescapable: Someone must always be first, and new regulation may come without much warning. But there are various nonconstitutional devices that can, and often should, be used to mitigate the burden imposed on the first rank of newly regulated owners. Exempting already developed lands from the new rules (grandfathering) is one such mechanism; allowing variances for hardships is another. Both were ultimately employed in the South Carolina law that gave rise to the Lucas case. ${ }^{84} \mathrm{~A}$ gradual phasing in of new regulations is another possible mitigation strategy. ${ }^{85}$ Exemption of individual homesites from subdivision regulations is another device for insulating the most vulnerable individuals, while still subjecting the majority of fragile lands to the coverage of new laws. ${ }^{86}$ Not every such technique will be appropriate in every situation, but these examples illustrate that there are many ways to blunt the impact of transition to new legal regimes.

\section{Toward a New Definition of Property}

\section{A. Public, Planned, Ecosystemic}

Assuming no compensation and a willingness to look anew at the nature of rights in land, what might property rights designed to accommodate both transformational needs and the needs of nature's economy look like? They would, at the least, be characterized by the following features:

1. Less focus on individual dominion, and the abandonment of the traditional "island" and "castle-and-moat" images of ownership. ${ }^{87}$

2. More public decisions, because use would be determined ecosystemically, rather than tract by tract; or more decisions made on a broad, systemwide private scale.

3. Increased ecological planning, because different kinds of lands have different roles.

4. Affirmative obligations by owners to protect natural services, with owners functioning as custodians as well as self-benefitting entrepreneurs.

To some extent, each of these changes already can be found in contemporary land use management. Extensive public regulation, active participation by the community in determining how land shall be used, and affirmative obligations imposed on private developments have increasingly become part

84. 112 S. Ct. at 2898 n.11 (citing S.C. CodE ANN. § 48-39-290(B), (D)(1) (Law. Co-op. Supp. 1991)).

85. See note 70 supra (discussing Pennsylvania's phased abolition of slavery in 1780).

86. E.g., CAL. Gov'T CODE $\$ 66426$ (West 1983) (exemption for minor subdivisions).

87. The fundamental role of property as a guardian of privacy is not threatened by the ecological perspective. Disregarding boundaries for purposes of ecosystem management should not necessarily impair their importance and use to protect human exclusion rights. 
of the land use process. The demands of the economy of nature, however subtly, have worked their way into the governance of land use. Wetlands regulation and coastal management have been in place in some states for nearly thirty years. ${ }^{88}$ Thus, the practice has preceded the theory, and change has occurred. After all, property is functional.

The true significance of changes being made, however, often was concealed under the all-embracing rubric of "harm." 89 Justice Scalia was correct: "Harm" is a paint that covers any surface. Judicial failure to ask why land management had changed so much, and to produce a plausible justification for the ongoing revision of property rights, has probably been one reason landowners see themselves as victims of injustice. The issue, however, has finally come to the surface. As the demands of the economy of nature mounted, exposure of the fundamental tension between the economy of nature and the transformational economy was inevitable. Lucas is just the vehicle for its emergence.

\section{B. The Usufructuary Model}

How would an owner's rights be defined in a property system that served both of the economies described here? Perhaps the closest existing model is that of usufructuary rights..$^{90}$ The owner of a usufruct does not have exclusive dominion of her land; rather, she only has a right to uses compatible with the community's dependence on the property as a resource. ${ }^{91}$ Thus, for example, one may own private property rights in a navigable river to use the water, but those rights are subordinate to the community's transportation needs in the river. ${ }^{92}$ The private use may be entirely eliminated where the community's navigation needs so require. ${ }^{93}$ Usufructuary rights have already developed in water because rivers and lakes were viewed as continuous and interconnected, not as separable into discrete segments. Many people depended on the rivers and lakes while numerous individuals also held pri-

88. E.g., Dooley v. Town Plan \& Zoning Comm'n, 151 Conn. 304, 197 A.2d 770 (1964).

89. Such is the case in Justice Blackmun's dissenting opinion in Lucas, 112 S. Ct. at 2909-16 (Blackmun, J., dissenting).

90. Blackstone speaks of the usus fructus as a "temporary right of using a thing, without having the ultimate property, or full dominion of the substance." 1 WILLIAM BLACKSTONE, COMMENTARIES ON THE LAW OF ENGLAND book II, 262.63 (1867). The idea is central to American water law. See 1 Samuel C. Wiel, Water Rights in the Western States 14-21 (3d ed. 1911). One does not own a river, but can acquire use rights in water taken from a river. A river itself, or at least a navigable river, is a resource that is held in trust for the public, but it is amenable to private uses compatible with the trust. 1 WATERS AND WATER Rights $§ 53.1$ (Robert Emmet Clark ed., 1967).

There are various versions of usufructuary rights. Cronon describes the usufructuary property system of aboriginal New England people as a right to use what was produced by one's labor, with the remainder available to others for their use. CRONON, supra note 54, at 62-63. Land was at once a private and a community resource.

91. Technically the community right may be called a servitude. The presence of the navigation servitude effectively reduces an owner's property interest to a usufruct. See, e.g., United States v. Willow River Power Co., 324 U.S. 499 (1945); Eva H. Morreale, Federal Power in Western Waters: The Navigation Power and the Rule of No Compensation, 3 NAT. RESOURCES J. 1 (1963).

92. See Willow River Power Co., 324 U.S. at 499.

93. See Gibson v. United States, 166 U.S. 269 (1897) (holding that a government dike may cut off access of riparian proprietor to navigable water). 
vate property interests in the resources. These characteristics made water unsuitable for complete privatization.

These very features-physical interconnections and community dependence on a resource's natural functions-characterize land in an ecological perspective. A usufructuary system drawing on precedents like the navigation servitude would subordinate private use to demands for the maintenance of natural services, even where the private owner's property is left valueless. The American experience with navigable waters reveals that property rights can exist in a dual status, serving both private and community demands. In most instances, communities accommodated private uses of these waters, but they also continuously protected the public rights of navigation. Property that serves both the transformational and ecological needs of contemporary society seems no less conceivable.

The notion that private property interests should be subject to some public claim or servitude, both limiting full privatization and demanding that any private benefits be compatible with public goals, is not uncommon. It was conventional public policy in frontier settlements to grant land on the condition that it be put to productive use within a reasonable time. ${ }^{94}$ There was no right to hold it for investment as an appreciating asset. ${ }^{95}$ Private uses had to promote community goals. Likewise, traditionally, valuable mineral rights were not the surface owner's, but were dedicated to the nation, a precept that early American law adopted: One-third of all gold, silver, lead, and copper found under land that had otherwise been conveyed to individuals was reserved to the United States. ${ }^{96}$ In a similar vein, early acts of Congress prohibited cutting live oaks and red cedars on private land because they were especially needed for shipbuilding. The trees were not subject to private ownership but were held as inherent property of the nation. ${ }^{97}$ Finally, as James Ely describes, "[t]he theory of republicanism, influential during the revolutionary era, subordinated private interests to the pursuit of the public welfare.... [T] ought to be subservient to public uses, when necessity requires it." "98

None of these examples is perfectly analogous to the needs of an ecological era, but they do reveal that privatization was never as complete as is often assumed today. They provide a precedent for the proposition that property can serve two masters: the community and the individual.

94. "[T]he New England colonies frequently required settlement to validate a land grant .... Headright grants commonly specified that the land must be brought under cultivation within a certain number of years." ELY, supra note 63, at 18.

95. To acquire land under the Homestead Act of 1862, for example, applicants had to "swear that the land was intended for actual settlement and cultivation and that the entries were not being made for any other person. Five years' residence on the land and cultivation were required before the homesteader could prove up and take title." PaUl W. Gates, History of PUBlic LAND LAW DEVELOPMENT 395 (1968). Congress allowed commutation of those requirements for settlers who needed title to borrow on the land, or to sell it. Id.

96. MCDONALD, supra note 82 , at 19.

97. Id. at 32.

98. ELY, supra note 63, at 33 . 


\section{ViI. The Problem of Governmental Abuse}

The navigation servitude has served well because it has been exercised with circumspection, and the same was probably true of the other public claims noted above. Where property has a dual role, there is an increased potential for abuse of power. ${ }^{99}$ The Lucas majority insightfully notes that, because developmental uses of land are no longer viewed as unambiguously desirable, there is an enhanced risk that governments will excessively demand the maintenance of natural conditions. ${ }^{100}$

The problem of abuse is not new, but it may well become more intense as traditional property distinctions fade. As noted earlier, public/private distinctions become even less clear in a dual land economy, and traditional notions of harm, externalities, and nuisance will not indicate government overreaching in the name of the economy of nature. There is certainly a risk that a majority of neighbors will be able to oppose undesired urban development by exaggerating the importance of ecological services performed by undeveloped land in their neighborhood.

As the services of the economy of nature are increasingly recognized, however, a consensus can be expected to develop as to which functions are important enough to demand maintenance. A consensus concerning the range of acceptable burdens on landowners will doubtless emerge-just as during industrialization, society determined the extent to which land owners would have to tolerate the new burdens of modernity, such as noise, traffic, and pollution. The determinations of that era, in fact, comprise much of the "relevant background principles" of nuisance and property law to which Justice Scalia refers in Lucas. ${ }^{101}$ Still, some enhanced judicial willingness to protect against arbitrary governmental regulation, ${ }^{102}$ and to assure proportionality between ecosystem needs and imposition on private uses, is needed to achieve an acceptable balance between the demands of the transformational economy and those of the economy of nature. ${ }^{103}$

99. For example, in United States v. Rands, 389 U.S. 121 (1967), the United States condemned land at a low price because of a navigation servitude, destroying the owner's right to sell to the state at a high price. The federal government then sold the land to the state at a very low price, unjustly enriching the state, which failed to make any public use of the land itself.

100. 112 S. Ct. at 2895.

101. Id. at 2901.

102. See, e.g., ELY, supra note 63, at 17 (citing Locke, Trenchard, and Blackstone); MCDonALD, supra note 82, at 74 . Arbitrariness is not the only concern. There is an equal protection element in the Takings Clause, as Justice Stevens' dissent in Lucas observes. 112 S. Ct. at 2920. Economic dealings by local governments in their entrepreneurial capacity are also an important concern. Ordinary physical appropriation, where government simply substitutes itself as a user of land in place of a private owner, is an obvious case where compensation is required. Compensation is also appropriate where government downzones in order to later acquire the property at a lower price; or where it sells a developmental interest (such as an oil lease) and then through regulation takes back the interest without payment to enrich itself, in the absence of any provision reserving such power. See generally Joseph L. Sax, Takings and the Police Power, 74 YALE L.J. 36 (1964).

103. Such an approach was suggested years ago in an excellent article by Zygmunt J.B. Plater, The Takings Issue in a Natural Setting: Floodlines and the Police Power, 52 TEx. L. REv. 201, 24356 (1974). Judicial oversight might be engaged under the requirement set forth in Agins v. Tiburon, 447 U.S. 255,260 (1980), that regulation substantially advance a legitimate state interest-so long as 
If the Lucas majority simply had suggested that heightened judicial scrutiny should be triggered when regulation deprives an owner of all economic value, ${ }^{104} \mathrm{I}$ would have no quarrel with the opinion. Such a rule of thumb would single out those owners who bear the heaviest private burden of the new ecological era. One might sympathetically view such owners as having lands that never would have been privatized in an ecologically sensitive world. Moreover, when regulation leaves no opportunities for private use, it also does not leave room for adaptive behavior by owners as an alternative to demands for compensation.

Such scrutiny would put regulators on notice that they too should seek adaptive solutions to avoid excessive regulation of private uses. Just how much judicial scrutiny such a standard would entail and what burden of justification on regulating governments the standard would impose are questions to which answers can evolve. Instead of responding by freezing outdated conceptions of property, as does the Lucas majority, by using a crabbed definition of property and its corresponding categorical rules, courts could respond with flexibility to governmental excess and to the pains unfair regulations inflict on landowners. ${ }^{105}$

Where exactly courts should intervene in this transformative era remains uncertain. The implications of the changes I suggest are dramatic, and the negative implications for many traditional proprietary opportunities considerable. Lucas' outdated view of property, however, is not satisfactory in an age of ecological awareness. Despite Lucas' inept ultimate resolution, for the first time the Supreme Court has recognized the profound implications of the ecological perspective on traditional property rights-a perspective the Court had previously ignored. In that respect, the Lucas Court promotes greater understanding of one of the most important problems of our day.

the presumption of the constitutionality of legislation is not subverted. Such a standard could be used, for example, against legislation that completely bans construction in part of a city simply to make it marginally more attractive to tourists.

104. Any such concern with the degree of loss would have to prevent landowners from breaking off, and trading in, only "forbidden" fragments of land. One might imagine any number of approaches designed to protect against such maneuvering, such as refusing to recognize the subdivision of land following enactment of restrictive use laws.

105. The approach suggested here is congruent with the multi-factor test proposed by the Court in Penn Central Transportation Co. v. New York City, 438 U.S. 104, 124 (1978). In that case the owner was obliged to play a custodial role, maintaining the structure's architectural values for the community so long as it still earned some economic return. Penn Central, and historic preservation cases generally, can be thought of as conceptual precursors to Lucas in recognizing community claims on private property in the name of national heritage. See Joseph L. Sax, Is Anyone Minding Stonehenge? The Origins of Cultural Property Protection in England, 78 CAL. L. REv. 1543 (1990). 
HeinOnline -- 45 Stan. L. Rev. 1456 1992-1993 